\title{
Evaluation of Grammatical Understanding of the Adjectives
}

\author{
Dr. Helena Grillo ( Mukli) \\ University "Aleksandër Moisiu" Durrës \\ Department of Albanian Language Albania
}

Doi:10.5901/jesr.2014.v4n4p326

\begin{abstract}
Planning in the field of linguistics needs to be made by research and measurements in recognizing grammatical structures and their uses. At this stage of its development the Albanian language outlines between concrete use, of controversial changes among linguists. We will try to measure the frequency of use of one of the main parts of the lecture, the adjective. The linguist experts are obliged to seek various ways and means of practical use of the adjective, their objectivity and validation should be proven. Study of this class of words has began early on, first in grammar from domestic or foreign linguists. The adjective puts in evidence a feature of one item whose name fits in genus, number. In the semantic level adjectives are divided into two groups : qualitative and relative. Our work aims to measure concrete uses of the above mentioned adjectives and analyze their uses in certain forms. The measurements will be made on a group of children, who first, should be tested for their lexical accuracy of the adjectives. The research is done in a way that by showing the page to the child were are several icons and right way they read a sentence. The job of people who conduct the experiment is to just show the icon for which the children respond to the sentence. The child to succeed in this experiment has no need for expressive talk just enough to show with the finger. Since the selected kids for measurements are from 5 to 7 years old, the research will highlight with concrete results the use of qualitative and relative adjectives during their speech. The research will bring valuable material in the field of linguistic planning and will serve us for analyzing the way children talk.
\end{abstract}

Keywords:grammatical development, children, lecture, adjectives

\section{Introduction}

The Albanian linguistic studies lack the methods and helping instruments which assist in the recognition of the degree of children linguistic development. Based on global linguistic studies are determined the phases that this development goes through. In our study we will surpass the third phase where the child has acquired the language in a certain level and we will study the next phase, where the child acquires step by step the language grammar, up to 5-7 years old where the level is similar to an adult ( Memushaj, 2011, p 312).

This variety of studies in the linguistic area opens the way of linguistic studies, as our study which will help in the deepening of linguistic studies in children, and will determine objectives between the validity of the test used to validate the language, the degree of language acquisition, mainly measurements of the grammar use understanding of adjectives and their degrees.

First of all, it is very important to determine if the difficulties are only in the expressive forms as in the use of expressions, or are they in the forms of understanding. It is necessary to analyze some cases in order to determine if the difficulties are semantic or grammar wise. Which of the adjective degree does the child use without difficulty and which not?

A particular problem in our environment presents the surpass of the understanding component in diagnosing, for which in our practices we only react when the signs of non-understanding are obvious. This study serves for diagnosing the phenomenon that happen in children with speaking problems, but it is not the main aim to treat this phenomenon.

\section{Overview}

According to various schools of linguistics, there are different studies for the degrees of the adjective. From Platon to Aristotle the adjective is seen as a subclass of verbs, but the alexandrines and their descendants as a noun subclass.

Albanian grammar is structured by foreign people. They had a practical aim and their help had only descriptive character.

The adjective is described since the ancient Albanian grammar "Grammatical surveys for Albanian language" from F. M. Da Lece (Lece, 1716) even though in these descriptions the adjective was not recognized as a independent part of the language, but is described together with the noun. Later on, in the reviews of J. Georg Fon Han for adjectives in 
"Albanian Studies ( Hahn,1854) Dhimiter Kamarda in "A model of compared grammatology of Albanian language " (Kamarda, 1870) has a variety of notes and reviews for word formation, degrees, the gender and the plural of adjectives.

The first Albanian author that modeled the adjective structure was K. Kristoforidhi (Kristoforidhi, 1882). In his grammar he described in details the adjective declension for the three genders, the declension of the adjective in collaboration with the noun (before and after it); the adjectives that come from adverbs, ( i/e shpejtë "fast", from nouns ( i/e artë, golden), from verbs ( i/e hapëtë, opened), form participles ( $i$ mbyllur, closed), from abstract nouns. The degrees of the adjectives they know the affirmative, comparative (higher and lower), superlative (absolute and relative).

Our study will be based on the thoughts of Albanian grammatologists "The grammar of Albanian Language 1" a publication of the Academy of Science ( ASHSH, 2002) .

The adjective is a modifiable part of speech that describes a noun. The adjective has its degrees and the grammar categories of the gender, number and nominative which are all dependent on the noun it describes. In grammar it is only given the main categorical meaning on the adjective as a feature understood as a characteristic, a feature of the recognizing relation.

According to the lexical meaning, it divides the adjectivs in: qualifying adjectives and relative adjectives. In our study, as for the classifying according to the semantic meaning we are based on the thought of V. V. Vinogradove "the differences among the qualifying and relative only in a small degree is determined from the morphological features", the core of this difference is "lexico-semantic and expressive- stilistic" ( Vinogradov, 1947). From this pint of view all adjectives used in the test are treated as equal, like words that label quality.( Demiraj, 1966, p.66)

\section{The Grammar Categories of the Adjectives}

Gender: feminine, masculine, neutral ( toward extinction)

Number: singular, plural and double relation

- Nominations

- $\quad$ Degree it categorizes the adjective and the adverb. It is expressed in analitical form

The affirmative degree just labels the name it describes.

- $\quad$ the comparative labels comparable features and is expresed in particles or adverbs. The labeled quality might be in equal or unequal comparative degree, with its four subdeegres and the models for each:

Equality comparative $=$ as + adjective + as : kaq zbavitëse sa brengosëse (as fun as concerning).

Unequality comparative separated into:

- $\quad$ decrease comparative $=$ less + adjective + than

- $\quad$ increase comparative $=$ a)more + adjective + than (with both parts of the comparative) më të ashpër se të parët ( tougher than the first)

b)adjective +er (no second part expressed) më të vështirë (harder).

Superlative degree labels a quality of one thing higher than the whole group (më $\boldsymbol{i}$ vogli, the smallest)

The sceme of the adjective classification:

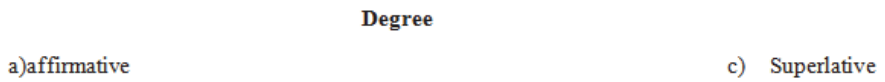

b) Comparative

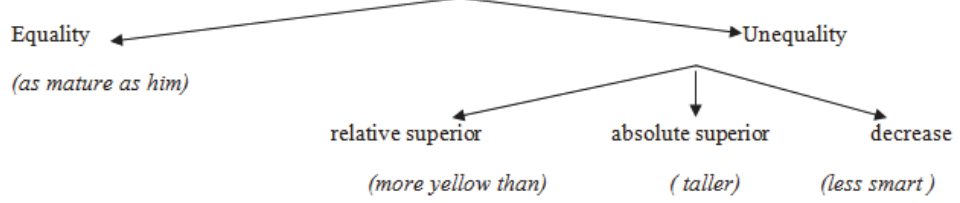

\section{Methodology}

The methodology of this study is very complex and uses many elements and techniques which are based on theory and practice in order to give a clear view of language development. The theoretical material will serve for comparing the different thoughts and developments of the various phenomenon under the study.

The tests for developing a language test, which will measure the language acquisition, and mostly the use of different categories of adjectives, is the ultimate test for such studies in the linguistic area, where the need for these kinds 
of studies and real measurements is really high. The test offered is appropriate for Albanian children and the measurements are done within the grammar structure of Albanian language. The test measures the knowledge of the grammar structure and their use. With the individual testing we aim to measure the knowledge and the use of adjective degrees of 80 children of ages 5 and 7 years old. In the test realization we notice other features related to adjectives, mainly in the use of gender and number use. We also aim to gather data and facts on Albanian language use especially in the phrases which show good acquisition of the grammar structures, is required to describe various adjectives, in adaption with the related nouns. The persistence in the fact noticing makes the main part of behaviorism, wich is the methodological bases of our study.

Figure 1: Language test

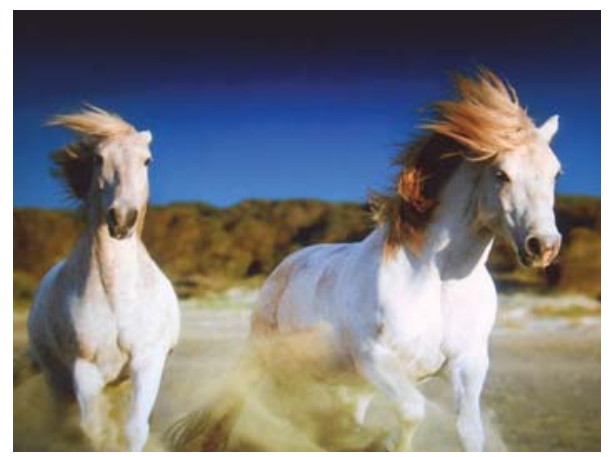

1. Kali është i bardhë (The horse is white).

2. Kali i parë që vrapon, është më i madh se tjetri (The first running horse is bogger than the other.

3. Qielli është thellësisht blu (the sky is totally blue).

4. Qielli eshtë i kaltër (the sky is blue).

5. Kuajt janë (The horses are.....)

\section{Figure 2}

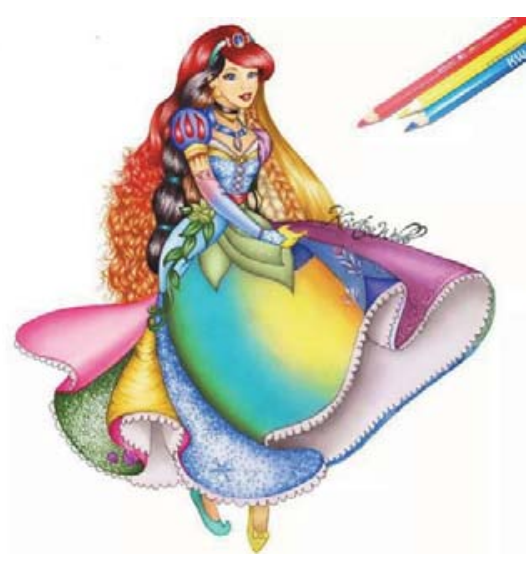

- Choose one of the following words:

1. Flokët e vajzës janë shumë të gjatë (the girl's hair is very long)

2. Flokët janë jashtëzakonisht të gjatë (the hair is extremely long)

- Choose one of the adjectives in the parentheses:

3 The shoes are ...... (different, beautiful, with bows, yellow, blue)

4 The dress is ....... ( beautiful, long, colorful, with lots of colors)

6. The girl's hair is .....(longer, more beautiful,) than my hair 
7. The red pencil is ...... (the longest, longer).........

8. The yellow pencil is .. ( the shortest, shorter)...

58 The blue pencil is (longer than the yellow pencil)

9. The blue pencil is (shorter than red pencil)

Figure 3: "Happy Teacher's Day"

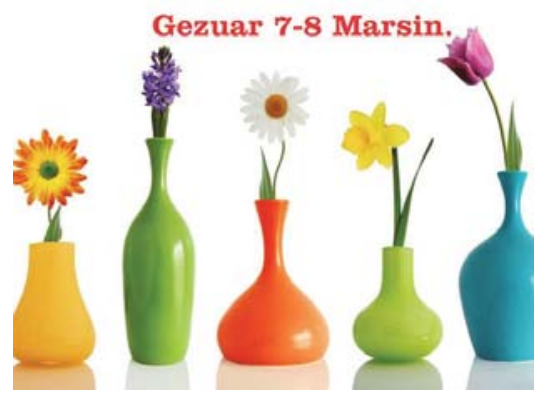

1. The green vase is ( the tallest, taller) from all the vases.

2. The green vase is ( very long)

3. The green vase, that has the yellow flower is the shortest, shorter than all vases.

4. The flower in the green vase is very yellow.

5. The yellow flower is on the green vase.

6. The orange vase has white flower.

7. The lilly is in the blue vase.

8. The green vase is ........

9. The yellow vase is......

10. The blue vase is......

During the selection of the participants from the educators and the parents there were data required for these children. From the study we excluded the children who have had difficulties in the psycho-social development, bilingual children or the ones who have been abroad, and the children who underwent speech therapy. In the beginning we tested the children to recognize the words (nouns, adjectives, and verbs) that will be used in the test, in order to determine if the mistakes are from the not understanding of the words or from the not understanding of the grammar.

\section{Hypotheses}

The main question is that up to which age goes the grammar development, and up to where is expected the maximal level of understanding? Are the degrees of the adjectives and their use acquired in the same level?

Based on the studies for the above tests we realize the qualitative assessment of understanding, which is done after the knowing if the individual has difficulties with understanding and it is necessary to explore in details the nature of the problem. We notice that the children who have understanding difficulties, as a result also have difficulties with the grammatical use of adjective degrees. After the problem determination there are some questions: are there any specific problems related to grammar or overall disorders; what grammar structures present particular difficulty. We will find out if the mistake's profile is similar to the typical profile of the age or are there any qualitative differences.

\section{Results}

There were 80 children tested with 3 figures, where each of them measured the level of knowledge of adjective degree use and has particular specifics, related to adjectives that describe colors. We chose adjectives in order to compare, in a later phase of language cooperation that does not speak Albanian. We should accept that the relation between the sign of the color and its meaning is not easy. The change of the reference from red to orange, green and blue can be described as a colorful change in tones. We are not going to take into consideration the relation to color and meaning among 
individuals, as we are considering an Albanian speaking community, by making sure to test children who have no problems in color determination, which in the community they are: black, white, red, silver, yellow, orange, blue, green. We are presenting tables of the use of grammar forms according to the numbers, we have taken as correct all the forms used from the grammar point of view and there were no mistakes in non correct use of colors.

Table 1: The presentation of participants' number according to the gender and age

\begin{tabular}{|c|c|c|c|}
\hline Age group & Male & Female & Total \\
\hline $5.0-6.0$ & 16 & 24 & 40 \\
\hline \multicolumn{4}{|l|}{} \\
\hline Age group & Male & Female & Total \\
\hline $6.0-7.0$ & 13 & 27 & 40 \\
\hline
\end{tabular}

The results taken from the test

Figure 1

\begin{tabular}{|c|c|c|}
\hline Words & Correct & Wrong \\
\hline 1 & 40 & 0 \\
\hline 2 & 36 & 4 \\
\hline 3 & 33 & 7 \\
\hline 4 & 40 & 0 \\
\hline 5 & 32 & 8 \\
\hline
\end{tabular}

Figure 2

\begin{tabular}{|c|c|c|}
\hline Words & Correct & Wrong \\
\hline 1 & 35 & 5 \\
\hline 2 & 40 & 0 \\
\hline 3 & 40 & 0 \\
\hline 4 & 40 & 0 \\
\hline 5 & 25 & 15 \\
\hline 6 & 20 & 20 \\
\hline 7 & 27 & 13 \\
\hline 8 & 38 & 2 \\
\hline 9 & 32 & 8 \\
\hline
\end{tabular}

Figure 3

\begin{tabular}{|c|c|c|}
\hline Words & Correct & Wrong \\
\hline 1 & 15 & 25 \\
\hline 2 & 40 & 0 \\
\hline 3 & 38 & 2 \\
\hline 4 & 36 & 4 \\
\hline 5 & 40 & 0 \\
\hline 6 & 40 & 0 \\
\hline 7 & 40 & 0 \\
\hline 8 & 35 & 5 \\
\hline 9 & 38 & 2 \\
\hline 10 & 37 & 3 \\
\hline
\end{tabular}

The main parts of speech are meaningful in the real word understanding, and the auxiliary parts of speech help in the overall meaning of the sentence. In this point of view the children do not lack the lexical understanding (the vocabulary meaning). The whole linguistic meaning of an expression is made of the lexical meaning of separate words and "the structural meanings" (Lyons, 2011, p.402). The term "structural meaning" of Fries are at least three different types of semantic types: 1. Understanding of grammatical elements ( characteristic of secondary parts of speech and grammar categories); 2. Understanding of grammatical functions, as: subject, object, determinants elements; 3 . Understanding in the sense of classification of various sentence types related to the "affirmative", "question" and "imperative" meanings". In general, from the analyses of the test results we notice that the children lack the first type of semantic functions related to the "structural meaning".

Form the analyses of the previous data we notice that the grammar norms are not totally acquired from the children of two age groups. If we compare them in the grammar category of the degrees, we see that the affirmative and superlative are well acquired. The children intensify the "form" of affirmative to express the superlative. This comes as result of Albanian language characteristic, where the affirmative creates the same meaning as the superlative. Too often is difficult to have the meanings separated and cleared between these two degrees.

The comparative form is harder to understand from the children. The mistakes in the use of this form come as a hesitation to differentiate which of the things has a higher degree, because both of them have the same quality. We think that most of the children understand the comparative relation, but from the grammar point of view, they do not give the right analytical form. This is proved by parallel structuring where the child does not have any difficulty to label the color blue, in relation to the sea color. In cases where the children are free to select the degrees of the adjectives we notice that they choose affirmative and superlative forms, especially the absolute superlative. In this last case, they are helped by the emotional changes (the prolongation of word forming particles as shuuиuumëëëë veryyyy, tepëëëër, a loooot, deeeeeeeeeep thellëëëësisht). Children are very creative in their language and correctly put the noun with the determining adjective. They are able to generally describe: the colorful dress, full of colors and when the relation is very complex, they use the adjective in the right form form the word forming perspective.

We have noticed that the children have difficulty to compare the superlative forms and comparative of absolute superlative. Almost all the language forms that express the comparative form of the absolute superlative are used wrong. This form is used more often like :Vazoja e gjelbër është ( më e gjatë) nga të gjitha vazot [the green vase is taller of all 
vases], instead of the correct form: Vazoja e gjelbër është ( më e gjata) nga të gjitha vazot [the green vase is the tallest of all vases]; Vazoja e gjelbër, që mban lulen e verdhë është më e shkurtër nga të gjitha vazot [the green vase that holds the yellow flower, is shorter of all vases], instead of the correct form: Vazoja e gjelbër, që mban lulen e verdhë është më e shkurtra nga të gjitha vazot [the green vase that holds the yellow flower is the shortest of all vases; Lapsi i kuq është më $i$ gjatë [the red pencil is longer], instead of the correct form: the red pencil is the longest: Lapsi i verdhë është më $i$ shkurtër [the yellow pencil is shorter], instead of the correct form: Lapsi $i$ verdhë është më $i$ shkurtri [the yellow pencil is the shortest].

The correct grammar form goes to the process of noun formation, which is very hard to be understood from the children of this age group. We have noted that the mistakes are not only in the forms of dialect, but also in the children language formation as: të lejlajta [purplerer], bardh [whitish], bardhë [white], kalt [bluish], verdhë [yellow], të dy bardhë [both white] etc, which are not part of this study.

\section{Results}

In the phase of the linguistic studies where we find ourselves, we find it necessary to measure the grammatical use. In our study we tested 80 children in order to measure the acquiring level of the grammatical category in the adjective degrees. The categorization is a grammatical level which is only used for adjectives and adverbs. This degree shows the level where the describing quality is found.

The data of our testing we noticed that the degrees of adjectives are not acquired the same in various age groups. The affirmative degree, accepted as the base form, without the morphological indicators is best understood from the children. The most problems are seen in the subcategories of comparative, as a result of hesitation that where is the characteristic of the item described. This problem is not only seen in children, but in other users of the language.

Based on the facts seen, we state that the level of language acquisition in the language community under the study, is not whole and the lack comes from understanding of the grammar meanings. This brings the result that the children of this age group are not able to understand all the grammar categories and to use them in the proper way, especially the degrees of adjectives.

\section{References}

R. Memushaj, Hyrje në gjuhësi, Botimet Toena, Tiranë 2011, f.312.

I. M. Da Lece, Osservacioni grammaticali nella lingua Albanese, Roma, 1716.

J. Georg von Hahn, Albanesische, Jena, Heft II, 1854.

D. Kamarda, Saggio di grammatologia comparate sulla lingua Albanese, Firenze, 1870.

K. Kristoforidhi, Grammatiki tis alvaniqis Glosis, Kostandinopojë, 1882.

ASHSH, "Gramatika e Gjuhës Shqipe 1" Tiranë, 1976.

V.V. Vinogradov, Russkij jazyk, Moskva, 1947.

Sh. Demiraj, Morfologjia e gjuhës së sotme shqipe, Tiranë, 1966, f.66.

J. Lyons, Hyrje në gjuhësinë teorike, Shtëpia Botuese Dituria, Tiranë 2011, f.402. 